\title{
SNERT: RITUAL-LITURGICAL MEASUREMENTS AND RECIPES FOR SOCIAL CAPITAL
}

Author:

Cas Wepener ${ }^{1}$

\section{Affiliation:}

${ }^{1}$ Department of Practical

Theology, University of

Pretoria, South Africa

\section{Correspondence to:}

Cas Wepener

email:

cas.wepener@up.ac.za

\section{Postal address:}

Department of Practical

Theology, Faculty of

Theology, University of

Pretoria, Pretoria 0002,

South Africa

\section{Keywords:}

liturgy; ritual; social

capital; commensality; table fellowship; Luke

\section{Dates:}

Received: 17 June 2010

Accepted: 02 Sept. 2010

Published: 03 Nov. 2010

How to cite this article:

Wepener, C., 2010,

'Snert: Ritual-liturgical

measurements and recipes

for social capital', Verbum

et Ecclesia 31(1), Art. \#407,

7 pages. DOI: 10.4102/

ve.v31i1.407

\section{This article is available \\ at:}

http://www.ve.org.za

\section{Note:}

This material is based upon work supported by the South African National Research Foundation (NRF) under grant number 65620. Any opinions, findings and conclusions or recommendations expressed in this material are those of the author and therefore the NRF does not accept any liability in regard thereto. This article was previously published in 2009 in the Dutch Jaarboek voor liturgie-onderzoek 25 , 229-246 and is reprinted here with permission.

(C) 2010. The Authors. Licensee: OpenJournals Publishing. This work is licensed under the Creative Commons Attribution License.

\begin{abstract}
The questions of how social capital is measured and how it is generated have received ample attention in recent years. This article is an attempt at making a modest contribution towards addressing these issues and specifically also as a contribution from the fields of Liturgical and Ritual Studies. It is argued that commensality can be taken as both lens/barometer with regard to the presence or absence of social capital, as well as being a potential generator of social capital. In order to arrive at this conclusion regarding food and the eating habits of humankind, the phenomenon of commensality and its relation to social capital is approached here from three different angles, namely Social Anthropology, New Testament Studies and Ethnography.
\end{abstract}

\section{BACKGROUND}

In 2008, a new National Research Foundation (NRF) research project commenced in South Africa under the title, 'Exploring the role of religious ritual in social capital formation for poverty alleviation'. This research project is a collaborative effort between South African and Dutch scholars. The main research question being addressed in this project is, 'How and to what extent does religious ritual contribute to social capital formation for poverty alleviation in South African communities?' The aim of the research is to better understand the role of religious ritual in the formation of social capital, as well as to use religious ritual as a potential lens to enhance understanding of the manner in which social capital is present in communities. In order to answer this question and work towards attaining the aims, two distinct fields have taken hands, namely Development Studies and Liturgical and Ritual Studies. Furthermore, the two most prominent concepts guiding the research process are social capital and religious ritual (cf. Wepener et al. 2010).

Social capital has been called the 'missing link' in social development. The argument goes that social capital is needed for other development efforts to be successful and to make the good functioning of society at large possible. There are many definitions of social capital, although the definition explaining social capital as consisting of a combination of bonding, bridging and linking capital currently enjoys wide acceptance and is also the definition used here (cf. Cilliers \& Wepener 2007:40-42). Very broadly speaking, bonding refers to the ways in which groups or individuals bond amongst themselves, thereby strengthening the group cohesion. Bridging refers to the ways in which groups or individuals can form relationships with people belonging to groups other than their own. Linking refers to the ways in which individuals and groups link with people or groups that are on a different societal level than themselves, for example poorer groups linking with richer groups. The second concept is religious ritual and here I will use the following working definition of ritual, namely:

Rituals are often repeated, self-evident, symbolic actions, that are always interactive and corporeal, sometimes accompanied by texts and formulas, aimed at the transfer of values in the individual or the group, and of which the form and content are always culture, context and time bound, so that the involvement in the reality which is presented in the rituals remains dynamic.

(Wepener 2009:36)

In this project, this definition is qualified so as to exclude such symbolic actions that do not pertain to religion in some way or other.

The funding that this research receives from the NRF falls under the overarching heading of 'Sustainable livelihoods' and within the subfield of 'The eradication of poverty'. The generation of social capital is associated with both the establishment of a sustainable livelihood as well as the eradication of poverty, which are both part of the bigger process of social development within which social capital is an essential ingredient. The unique contribution of this research project is that it explores the role of religion in the generation of social capital in general, but also the role of religious ritual specifically. Generally speaking, this project is thus about the role of the non-material and the uniquely religious in the generation of social capital that contributes to social development and, ultimately, to the eradication of poverty. In recent years, studies have looked at the role of faith-based organisations in service delivery in South African society. However, this new research project focuses instead on the role of core religious activities and religious ritual is introduced for this purpose.

Ultimately, the connection between the generation of social capital and the role of religious ritual within that process is not all that obvious, but it is exactly the aim of this article to explore that rather murky domain.

\section{INTRODUCTION}

How is social capital measured $?^{1}$ What are the dynamics of the generation or formation of social capital (cf. Cilliers \& Wepener 2007:39-55, as well as Swart 2006:346-378)? These are central questions

1.Cf. the website of the World Bank, specifically www.worldbank.org/ 'Measuring Social Capital' (14.01.2009) for examples and methods in this regard, as well as the article by F. Fukuyama entitled 'Social capital: the problem of measurement' (http://www. socialcapitalgateway.org/NV-eng-measurement.htm). 
for those who study social capital as a phenomenon. Answers to these questions vary considerably, depending on numerous factors, for example the academic field within which it is being approached. Both these questions will receive attention in this article, although obviously no final answers will be provided. What is presented here is only a modest attempt at fitting one very small piece of the larger puzzle called social capital. As has already been mentioned, this contribution comes from the field of Liturgical and Ritual Studies, here specifically combining Theology and Anthropology. Of particular interest are studies within these disciplines that take food and commensality and the rituals surrounding them as an object of research. The main aim of this contribution is to present the method and theory that the author would like to employ over the next three years in the scope of the above-mentioned research project in order to make a contribution to the central question that this research project attempts to address. The aim of this article is thus, firstly, the presentation of an approach and, secondly, a very preliminary exploration in this regard.

In his book The Philosopher's Cookbook, Martinus Versfeld (1983:38) remarks, 'Nothing is more indicative of what you are than your food and table customs'. He later also writes:

Archaeologists find pottery remnants at very great depths, and these tell them more about man than any other relict because they tell of his relation to the earth and to his fellows.

(Versfeld 1983:53)

Are Versfeld's observations correct? This basic question is also the main research question that this article wishes to address, namely 'Is there a demonstrable link between table fellowship and human relations in society or so-called social capital?' If Versfeld is correct in his observation (and it will be argued here that he is indeed right) then the hypotheses following this basic question are twofold, namely:

- Food and table fellowship (or commensality) are indeed lenses to better understand human beings and the ways in which they relate to each other. Phrased differently, the first hypothesis can read: table fellowship or commensality as a space is a lens through which social capital can be measured.

- The second hypothesis is that the table and commensality as studied in Social Anthropology and as presented in Luke-Acts, as well as insights obtained from fieldwork data, provide us with valuable guidelines regarding the inherent potential (and dangers) of table fellowship for the formation of social capital.

In this article it will thus be argued that commensality is both a lens for the measurement of social capital as well as a potential space for the generation of social capital.

In order to attempt to answer the research question and test the hypotheses, three distinct but related steps will be taken:

- Firstly, anthropological work relating to our theme will be consulted for a general discussion of how humankind's eating habits reveal a fair amount about their society and the relationships within that society.

- Secondly, the theme of table fellowship in Luke-Acts will be unpacked briefly. Seeing that this contribution is not a general religious exploration, but a (practical) theological one, the Bible is also consulted on the topic of eating habits and relationships and social anthropological theory is thus complemented with biblical insights. This second step complements the first by providing practical-theological guidelines regarding religious ritual and the formation of social capital.

- Lastly, the answers to questions used in a small-scale qualitative focus group activity in a church in the Eastern Cape (South Africa) village of Phepheni will be presented. In this last section, the social anthropological and biblical insights are complemented by empirical field work in a first and preliminary attempt to test the hypotheses in a local congregation.
Methodologically, this presentation is thus a combination of a literature study, biblical-exegetical work and a small-scale qualitative study. Together, these three small explorations aim to contribute to the development of a possible measuring instrument for the presence as well as guidelines for the generation of social capital.

\section{COMMENSALITY AS RITUAL LENS AND SPACE FOR THE FORMATION OF SOCIAL CAPITAL}

Although the main phenomena being studied here are food, drink and eating habits and also the rituals pertaining to them, the primary symbol to which the food and actions relate is the human body and human bodies plural. The human body being the primary symbol, food, eating habits and the concomitant rituals will be utilised here to decode the body as symbol. As such, these phenomena will also be used to decode the interaction between different human bodies. It is important to note here that the human body has often been described as a mirror image of the social body within which the body or bodies function (cf. Van Wiele 2007:202-203). Activities related to the periphery of the body are especially important, because these activities are closely associated with the borders and margins of the society within which that body is operating. ${ }^{2}$ Peripheral activities will include producing excrement from the body, such as saliva or urine and also material entering the body, for example through the mouth, such as food and drink, but also through sexual activities and rituals involving the sexual organs. A close look at the human body, especially as it pertains to the peripheral activities, reveals a fair amount about its surrounding social body. For example, a quick glance at what is being covered on a woman's body (and what not) while she is sunbathing on the beaches of Southern France compared to a woman sunbathing on an Iranian beach will reveal a fair amount about the social body in which that particular human body is sunbathing. The same is true about food and eating habits. What may enter a body as food and what may not, with whom a person may eat and with whom not, can reveal much about the specific human body (person), its relation to other human bodies and its relation to the larger social body within which it is operating (cf. Van Wiele 2007:177-209). But first we will take three steps back in order to revisit this argument in the conclusion of this article.

\section{The anthropology of eating}

In the latter half of the 20th century, one of the foremost scholars, not only in the field of social anthropology, but also of food studies as a subfield within the larger domain of anthropology, was the British anthropologist Mary Douglas (1921-2007). In her earliest writings from the 1960s, the seeds of a later, greater interest in the subject were sown and can already be detected at this stage. As an outspoken Roman Catholic, she often treated the seemingly insignificant as being not all that insignificant and amongst these apparent insignificances were the eating habits of mankind. In her classic volume, Purity and Danger, she deals with the concepts of the clean and the unclean, of purity and taboo, also and specifically as pertaining to ritual (cf. Douglas 1966). As soon as concepts such as purity and taboo are introduced in the sphere of religion and ritual, it is not long before food and eating habits become part of the discussion. ${ }^{3}$

Douglas defines dirt as 'matter out of place' and does so in opposition to more modern concepts of dirt that have more to do with hygiene and fear of illness. From this definition she proceeds to show that such a definition implies 'a set of ordered

2.So, for example, Mary Douglas writes: 'I suggest that food is not likely to be polluting at all unless the external boundaries of the social system are under pressure (Douglas 2007/1966:157)

3. Of course, the other topic closely related to the topic of purity is sexual behaviour which Douglas also discusses extensively, with ample examples from cultures all over the globe. 
relations and a contravention of that order' (Douglas 1966:44) and that 'where there is dirt there is system' (Douglas 1966:44). What follows is that there are symbolic relations between dirt and a system of purity and one of her examples helps to explain this system as well as the relativity of our notions of purity and dirt. '[F]ood is not dirty in itself, but it is dirty to leave cooking utensils in the bedroom, or food bespattered on clothing' (Douglas 1966:44-45). Douglas explains that the ways in which humans and societies behave towards dirt or 'matter out of place' is the fact that the dirt is 'likely to confuse or contradict our cherished classifications' (Douglas 1966:45). She also explains how those things in society that do not fit our ordered systems and classifications are potential 'powers and dangers' threatening our sense of order. In this regard she remarks that 'Ritual recognises the potency of disorder' (Douglas 1966:117). Society does not know how to cope with marginalised and borderline cases in relation to its ordered system. Rituals are consequently performed to keep these unclassifiable phenomena at bay, for example the rite de passage for someone in a transitional state. ${ }^{4}$ Rituals of purity and taboo relating to dirt are thus important in upholding a certain social structure.

With regard to food it is easy to classify water as liquid or bread as solid, but there are also substances that challenge our systems of classification, for example syrup or a sticky substance, which tends to be ambiguous or anomalous. In her chapter on the system of classification used in Leviticus (much criticised in later years), she further develops this notion by showing that animals were classified as being dirty or unclean if they did not fit a given system, for example amphibians that are not only land or water animals. ${ }^{5}$ Let me not get sidetracked, however, in order to move closer to food and classification within society as pertaining to human relationships.

In an article entitled 'Deciphering a meal', Douglas (1971) asks the question: 'If food is a code, where is the precoded message?' And she answers by stating that

the message it encodes will be found in the pattern of social relations being expressed. The message is about different degrees of hierarchy, inclusion and exclusion, boundaries and transactions across the boundaries. Like sex, the taking of food has a social component as well as a biological one.

(Douglas 1971:61)

In order to explain this practically, Douglas takes her home and her family's food and eating habits as point of departure. She explains that deciphering a meal is not an easy task to perform and that every meal of the week and year forms part of a larger, ordered pattern and can only be understood as such. Sunday lunch can only be understood in relation to Monday breakfast or Friday dinner, just as the Christmas lunch can only be fully understood in its relation to all the meals in the rest of the annual calendar. There furthermore are many requirements for an event to qualify as a meal and not just as drinks, which she explains by means of the use of utensils for eating.

Meals properly require the use of at least one mouth-entering utensil per head, whereas drinks are limited to mouth-touching ones. A spoon on a saucer is for stirring, not sucking.

(Douglas 1971:66)

Douglas expands on the requirements for an event to qualify as a meal proper, but our interest, however, tends to be related more to the meaning of food and eating in its relation to human and social relationships. What is important is to see how context bound the meaning of an action such as a meal is, because the criteria used by Douglas for a British meal in 1971 are surely not fully applicable to all African meals in 2010.

\footnotetext{
4.Douglas's explanations here are closely related to the work of Van Gennep and Turner on transitional rites (cf. Van Gennep 1996:529-536; Turner 1965; Turner 1969 and Turner 1972:390-412).
}

5.Cf. Douglas (1966) Chapter 3, entitled 'The Abominations of Leviticus'.
With all of this in mind, let us move on to meals and their relation to human and societal relationships. According to Douglas (1971), the intimacy or closeness of a relationship can be measured by the type of food that is shared between people:

Drinks are for strangers, acquaintances, workmen, and family. Meals are for family, close friends, honoured guests. The grand operator of the system is the line between intimacy and distance. Those we know at meals we also know at drinks. The meal expresses close friendship. Those we only know at drinks we know less intimately ... There are smaller thresholds and halfway-points. The entirely cold meal (since it omits a major contrast with a meal) would seem to be such a modifier. So friends who have never had a hot meal in our home have presumably another threshold to cross.

(Douglas 1971:66)

The symbolism in the substance of food itself and in its correlation to friendship is striking in Douglas's description. The sharing of solid food indicates solid relationships, just as the fluidity of drinks is an indication of the fluidity of the relationship between host and guest.

Thus, to sum up, part of the message of food and eating habits is that they communicate borders, thresholds and bridges in relationships. Rules or taboos regarding food and eating are used to keep a specific order in place. So, for example, I showed in an article some years ago how the form for the celebration of the Lord's Supper made use of such a taboo (cf. Wepener 2002:139-158). ${ }^{6}$ Therefore, the Eucharistic formulary that was in use in the Dutch Reformed Church (DRC) in South Africa during the period 1948 to 1969 has an especially long list of those who were not allowed to partake in the Eucharist in the DRC, inter alia 'all who did not obey their parents and governments'. Of special importance is that this formulation, in the 1970 revision of the formulary, was extended to 'all who wish to cause a schism and disruption in churches and state governments, all who commit perjury and are disobedient to their parents and the government'(Handelinge van die Algemene Sinode van die NGK 1970:727). This is a good example of how a protective taboo was used to help sustain a specific social order in South Africa. These kinds of taboo were there, to use words from the title of Douglas's book, for the sake of purity and to avoid danger. In the language of social capital it can be said that they were there in order to ensure a specific kind of bonding and to help guard against undesired bridging. Douglas also points to the fact that these boundaries are often more strictly kept by minority groups, for example an endangered group such as the Israelites or smaller castes within Hinduism (cf. Douglas 1966:153).

Another example accompanied by ritual legitimisation could perhaps be the well-known synodical decision of 1857 (cf. Wepener 2002:142 and especially Loff 1983), when it was decided that people from the same Christian denomination but different races would henceforth eat and drink ritually in different buildings. Although this decision can be read in plain and straightforward racist terms, one could ask whether it perhaps is a classic example of what Douglas is talking about, namely a minority group (Afrikaners) trying to protect their own borders and margins by means of a specific kind of commensality, thereby creating a very limited kind of social capital consisting almost entirely of only bonding capital? Have a good look at people's food and table customs and they will most probably communicate a fair amount about the people themselves and also about the society in which they live or the desired society they wish to create. Food and table customs are symbolic with regard to the human body, its relation to other human bodies and also its relation to the social body within which those bodies function. Therefore, the presence or absence of bonding, bridging and linking relationships in society can be measured by means of a close observation of people's eating habits, especially those governed by ritual legitimisation.?

6.See also De Visscher (1996:113) with regard to the functioning of protective taboos in religions when holy fare is consumed and Greschat (2008:300) for the concept 'taboo'.

7.This conclusion needs a lot of qualification. So, for example, every ritual and al meal etiquette are very context bound and can have a totally different meaning in another context. 


\section{Table fellowship in Luke-Acts}

Numerous recent studies (cf. Braun 1995; Finger 2007; Heil 1999; Love 1995; Neyrey 1991, 1996; Wepener 2009, 2010) show how Luke utilises table fellowship and commensality as a deliberate strategy, both in Luke and in Acts, in order to communicate his message. More than other authors of the New Testament, Luke is said to be sensitive to this theme and employs it as a rhetorical strategy in his writings. There is not enough space here to unpack all those texts in which table fellowship or other forms of commensality occur in his writings, seeing that they are numerous (Neyrey 1991:361-362). A quick glance at a couple will suffice and the idea is to point specifically to the fact that these occasions of table fellowship are descriptions of deliberate attempts at creating a specific kind of biblical social capital. I refer to this as 'biblical social capital' in the sense that there are examples of bonding, bridging and linking in these texts:

- At the table of Emmaus (Luke 24), hospitality towards a stranger (almost) leads to commensality with the stranger, but the table fellowship described, the blessing and the breaking of the bread lead to bonding, not only of the people of Emmaus, but also of those going back to Jerusalem to bond with the others.

- In Luke 7, Jesus dines at the table of Simon the Pharisee and there the unthinkable happens. A sinful woman touches a man by weeping on his feet and washing them with her hair. Here the table opened up a space for bridging between genders.

- Luke 14 is a beautiful chapter regarding table fellowship. Jesus once again reclines with a Pharisee, this time a prominent one, Luke tells us, but actually insults his host as well his host's other guests by trying to teach them better table manners (do not run for the seats in front; rather invite the poor, the lame, the crippled and the blind and not this rich bunch). This he embroiders on later in the chapter by means of the parable of the table in the kingdom of heaven where the poor, the lame, the crippled and the blind will be the guests of honour. What we have here can be called an attempt to explore the potential of the table for the generation of linking capital, linking the rich and the poor, amongst others. Putting the last first and the first last, etcetera.

- Then, of course, there are the texts in Acts, such as Acts 2 , where the early believers are practising a rather radical kind of koinonia by sharing a meal as well as possessions. In this regard, Reta Finger shows in her book, Of widows and meals, how scholars through the ages have tried to explain away this too radical a text (cf. Finger 2007:12-47). It is indeed quite a radical description of bonding - going the extra mile to share possessions. And then, of course, Luke gives us the account of Peter's vision of food, which leads to commensality between Jews and heathen and the crossing of ancient boundaries in chapters 10 and 11 of the book of Acts.

- In general, the Lucan texts dealing with commensality are rather radical, but, according to a poem (in translation) by the late South African poet, Sheila Cussons, on these texts. This Afrikaans poem is titled 'Terugkeer van Emmaüs' (1997):

He who created the world

- earth and stars and bread and wine -

was a glutton and a tippler.

(Cussons 1997:26-27)

If Mary Douglas's work can possibly assist in developing a kind of social anthropological measuring instrument with regard to the presence or absence of social capital, then Luke's writings can possibly assist in creating a recipe for social capital. To put it differently, the Lucan texts can assist us in the development of practical-theological guidelines for the liturgical and ecclesiological inculturation of more adequate habits pertaining to commensality in faith communities for the generation of social capital.

\section{Worship and eating in Phepheni}

However, both the notion that Douglas's work potentially provides us with a lens, as well as the notion of Luke providing us with guidelines should be tested. The method employed here to test the hypotheses is of a ritual-liturgical nature, making use of participatory observation. ${ }^{8}$ The idea is to only introduce a congregation, give the broad outlines of the method and present the questions that were put to the participants in a focus group activity, with some of their answers to these questions.

\section{The Corinthian Church in Phepheni and its Sunday worship}

One of the congregations that is participating in the NRF research project for the purposes of collecting data is, broadly speaking, part of the so-called African Independent Churches (AIC) in South Africa. According to the 2001 census statistics, these churches amount to $31.8 \%$ of the total of $79.8 \%$ of the South African population who call themselves Christians (Statistics South Africa 2001). The church is situated in the village of Phepheni, approximately 20 kilometres from Kokstad. There are three priests, of whom the leader is the Rev. Pungula Wellington Dingaan. The author met with the Rev. Dingaan at the beginning of 2008, just after the research project commenced. During November 2008 the author had the privilege of visiting Kokstad and the research team there again, as well as to attend a Sunday worship service with the Rev. Dingaan and conduct a small preliminary focus group activity. These visits will occur several times per year for the period from 2008 to 2011. The worship service that was attended will not be described here, seeing that it was quite lengthy, lasting more than four hours and actually entails a study all of its own.

\section{Focus group and questions posed}

After attending the worship service, the priest extended an open invitation to all present to attend a session during which questions could be posed. Of the approximately 80 people, more than half stayed behind. They were divided roughly equally between the sexes, but fewer younger worshippers stayed behind for the focus group than older people. The main aim of the project was explained to the congregation, as well as why this specific set of questions would be asked. An attempt was made to try to convey a basic grasp of what worship and everyday rituality had to do with the way in which they lived. Food and commensality were used as a lens or barometer. For this purpose of exploring the possible connection between commensality and social capital, three sets of questions were put to the respondents in three categories, namely food and commensality at church, at home and in the larger society. The questions had to do with how often, when, what and with whom the respondents eat in the three spaces of church, home and larger society. Presented here is, firstly, a summary consisting of a collection of representative verbatim answers, followed by a discussion of the answers under these three headings. The emphasis of the discussion falls on the manner in which the answers to these questions reveal something about the existing bonding, bridging and linking capital in these environments, as well as the potential for these elements or lack thereof. Lastly, it should be noted that the respondents are all first-language Xhosa speakers, for whom English is a second language. An interpreter was used who gave a fairly literal translation of the answers and the transcribed data is presented here as such.

\section{At church:}

We eat at the Eucharist which is celebrated four times a year. Furthermore, meals are also shared at weddings. The Eucharist is for special occasions and is celebrated by the priest after the regular worship service during services on Good Friday, in July, in October and on New Year. We eat at the above-mentioned four Eucharist services and also at weddings. At a funeral we don't eat. ${ }^{9}$ We then eat at home. When we go and have a funeral somewhere, wherever the funeral is we don't eat, we come back. When we bury a member

8.With regard to method in liturgical research, cf. Barnard (2000), Post (2001a, 2001b), Stringer (1989) and Wepener (2005, 2006a, 2006b).

9.Interestingly enough, meals are not shared at funerals, which is different to the custom in typical Black Reformed congregations in South Africa. 
this is our culture: At the burial site or where the funeral is taking place we don't put soil in the grave. When we come back to that place we ask for a chicken that we are going to cleanse ourselves with. We use the blood and gila. ${ }^{10}$ The meat we give to the family to eat. This blood and gila we use in a five litre pot of water. The blood and gila we wash and cleanse ourselves with. The reason for that is that we are the people who are healing people. When I come back to that place when I arrive here at home sometimes there are people who are sick and when I arrive here I have to cleanse myself because I have to heal them. That's how it happens.

At the Eucharist we eat wafers and drink red wine. During Easter we are fasting and don't eat. During Lent in the time going to Good Friday we are using fasting. We start eating on the Monday after Easter. Sometimes the others don't start eating on Sunday as they can, because they don't feel as freely after the fasting that they can eat so they eat only on the Monday. Yes, there are also many other times for fasting. There are other times when the spirits talk to you, you feel like fasting and you start fasting. It happens to an individual. By the vision and when the Holy Spirit speaks to that person, he or she decides to fast. There are also times we go to the mountains and there we make a fire and burn a chicken or sheep or small lamb as an offering. It is our culture as Corinthian Church people. If you remember the offering that Abraham and Isaac did on the mountain - we follow that culture. The reason for that is that we sometimes have visions that lead us to go and perform that ritual at the mountain. Only people who have been confirmed can partake of the Eucharist, however any visitors to our church who have been confirmed are welcome to join in. The men and women also eat and drink together during the Eucharist.

(Respondents)

Eating and drinking and rituals related to food, such as the one described above with the chicken, provides a lens to understand this culture a bit better. Before one can even start to speak about social capital and human behaviour related to that social capital, this ritual shows that there are certain categories pertaining to issues of clean or unclean, life or death and healing or illness that should first be considered. Although the respondents declared throughout that their church, the Eucharist celebration as well as all their tables were open and hospitable towards anyone in general, there may in fact be other borders guarding over the ways in which bonding, bridging and linking happens or potentially can happen in this congregation and community. The cleansing ritual is an indication of the importance of understanding the notion of healing in the community and more specifically of understanding the requirements for religious experts to practice such healing. The ritual thus reveals something of the importance of a kind of spiritual capital as a prerequisite for social capital in certain religious communities. In other words, the role of spiritual or religious borders regarding purity must be understood as a prerequisite for a good understanding of the existence and generation of social capital in this congregation and community.

Closely linked to this first observation is the fact that the only taboo that was mentioned with regard to partaking in the Eucharist interestingly enough had nothing to do with Baptism, but rather with Confirmation. Here again, the taboo is a subtle clue to understanding this congregation and community and is most probably an indication of the importance of the Spirit in the congregation's theological understanding. This suspicion is confirmed in part by the respondents' description of fasting in the congregation as an act inspired by the Holy Spirit, as well as of the role of visions for the performance of the ritual offering of a chicken, sheep or lamb. All these aspects provide an indication that the presence and generation of social capital in this congregation cannot be understood in its entirety apart from the respondents' belief in the presence and activity of the Holy Spirit and his influence on the members' behaviour.

10.According to one of the Xhosa field workers in this project, the gila is the giblets of the chicken.

\section{At home:}

We eat at home three times a day - breakfast, lunch and supper. In the morning at breakfast we eat porridge; during lunchtime we eat anything - rice, pap or sometimes samp; ${ }^{11}$ at supper - the same as lunch, rice, pap or samp. At Christmas time we have special meals. We then eat jelly and custard and other pudding and biscuits. But now it is not the same as it used to be before. Things have changed although people are struggling. [The author asks: 'How was it in the old days?'] Dull. In olden times they used to have rice during Christmas that was not something we eat during the course of the year or every day. As now we take rice every day. We don't wait now for Christmas to eat it. Things have changed. [The disappointment seems to be with the fact that something special like rice has become rather ordinary, thereby making extraordinary things ordinary.]

We always eat in the kitchen. The most respectable person is the father of the house who has his own special place and where he sits there is a small table they bring in front of him so that he can use when he is eating. You start first by giving the father of the family the food first, he's the one who receives it first, then you give the kids and the mother. We bless the food and then we eat. We always eat as a family. Sometimes if there is a visitor that comes while you are eating, you dish up for that person. We will eat with anybody who comes to our home.

(Respondents)

When talking about commensality as both lens and space for social capital, several important observations can be made from these responses regarding the eating habits of this congregation's members in their homes. Firstly, the prevailing importance of the role of the family in this community as a space for the formation of social capital should not be overlooked. Without romanticising the situation, it is important to note that the households eat together and do so very often. The situation should be seen in context, of course, namely the context of a fairly poor rural community in a remote area. However, it is significant that the information regarding their eating habits at home is a good indication of the family's potential for bonding capital.

The respondents' rendition of mealtimes at home also uncovers more about a community in which gender relations are still very traditional, with the father as the head of the household being indicated by him receiving food first, as well as having a special seat for eating. ${ }^{12}$ These traditional gender roles are very important to understand when bonding, bridging and linking are at issue, seeing that these gender roles also indicate certain boundaries that may not be crossed.

In general, the people eat maize products such as pap or samp, but sometimes also rice, for all three meals in the day. This food and how often they eat it obviously also conveys something about their financial situation, seeing that this is the cheapest kind of food available in their context. Lastly, it should be mentioned that the respondents generally were quite adamant about the fact that their tables and/or houses were welcoming to strangers, which opens up possibilities for bridging and linking capital in this context.

In the larger society: To the question, 'How often do you eat when you are not at church or at home?', the responses were:

Especially it's done by the young people like us when we take somebody out for dinner [a younger respondent answering]. For the elder people they don't do that because they think of their kids if they do that. If they go out and eat somewhere in town

11.Pap is maize meal cooked into a soft porridge and samp is corn kernels that have been crushed until broken, but not as fine as maize meal.

12.Cf. Wepener (2009:167) for a description of the hierarchy of importance within Xhosa families. In summary this hierarchy is as follows: 1 . Men (with a position like a teacher or doctor and older men) 2. Men in general 3. Women (with a special position in society such as teachers) and older women) 4 . Women 5 . Children position in society such as teachers) and older women
(before initiation for boys and before marriage for girls). 
they think, "what about the kids at home?" They prefer to eat at home. [This remark is embroidered upon later in this section in relation to Kentucky Fried Chicken and will there be explained in more detail.] Some people eat lunch somewhere else because they work for example on the road. We do eat at weddings. Also sometimes in neighbouring villages if there is a wedding, or a party or some ritual. We won't eat Kentucky [laugh] in town. We do not buy KFC and eat it, because if we buy it and eat it we think of our kids and what they will have at home. So then we can't have Kentucky. [Here the previous answer in this section was taken up again.]

(Respondents)

'Where do you eat in the larger society?'

Either at work, on the road ${ }^{13}$ or somewhere or at the wedding.

(Respondents)

'With whom do you eat and with whom do you not eat? Have you ever shared a meal with a White person?':

No, they have never, except for two persons who have done so in a work-related situation.

(Respondents)

'Have you ever shared a meal with a person who occupies a professional job?'

Yes, we do have teachers that are living around here that we eat with at weddings but we don't have doctors or lawyers around here.

(Respondents)

'Anything else about the subject you would like to share?'

We feel very happy to eat with other people because that makes the relationship, it is fellowship when we eat with other people.

(Respondents)

It should be noted how important rituals are in order to create occasions for eating and drinking and therefore for commensality, also over certain borders which would otherwise not have occurred. In this community, religious rituals and celebrations such as weddings are more important spaces in which bridging and linking capital are generated than, for example, people's work environment.

The references to Kentucky Fried Chicken (a fast-food chicken outlet) are, firstly, an obvious financial indication that the people in the congregation are generally not financially affluent. But, even more importantly, it conveys something about a culture of sharing and could possibly be a reference to ubuntu. ${ }^{14}$ This bonding should be qualified and, what is especially noteworthy is the bonding that exists between the parents and children, whilst the young adults admitted that they do sometimes eat in town at places such as Kentucky Fried Chicken.

When one reflects on the absence of bridging and linking capital between the members of this congregation and people in professional positions and White people, it should firstly be noted that there are very few professional people and no White people living in the village of Phepheni. The answers provided in this regard could thus rather be references to the fact that Phepheni is a fairly remote, isolated village than a real reflection of linking capital or racial relations in South Africa by the year 2008. However, if a group of more than 40 Black people in South Africa, fourteen years after the first democratic elections, say that they have never shared a meal with a White person, it is also a fact involving bridging capital that should not be ignored or explained away too quickly.

All these comments on the responses regarding the eating habits of the members of the Corinthian Church in Phepheni are

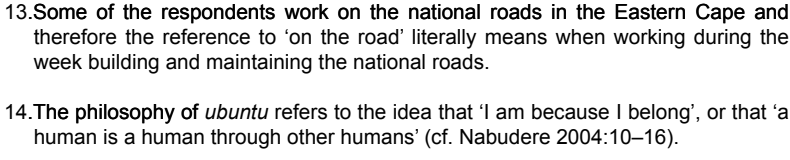

preliminary observations and, at this stage, do not pretend to be anything more. The explicit aim of this article is to explore the validity of the proposed hypotheses.

\section{COMMENSALITY AND SOCIAL CAPITAL}

As was mentioned earlier, this article is concerned primarily with the human body as primary symbol and the eating habits of humans and the rituals regulating those eating habits as symbolic in relation to the social body in which they operate and the human relationships within that social body. As Douglas (1966) puts it:

The rituals enact the form of social relations and in giving these relations visible expression they enable people to know their own society. The rituals work upon the body politic through the symbolic medium of the physical body.

(Douglas 1966:159)

This symbolic reference is, however, subjective and relative to each particular society that the body is mirroring.

This brings us back to Versfeld (1983):

But the cardinal point is that it is primarily food that relates us to one another, so it is food which relates us to God, since we can nowhere find God except in relating to people.

(Versfeld 1983:35)

It is also possible to translate this quotation, within the framework of our project, as 'Food is important as a lens as well as generator of social capital, also and especially as pertaining to the role of religious ritual in social capital formation'. Mary Douglas's writings on the subject support this thesis. So does Luke's use of table fellowship in his Gospel, as well as in Acts. And this is also confirmed by the people from the congregation of the Corinthian Church of Phepheni in the Eastern Cape province of South Africa. Douglas's work showed how food and eating habits and the rules and customs surrounding them, are bearers of a deeper message regarding society; they have the potential to be measurements for social capital. A careful decoding of these actions and customs related to commensality could uncover much about human relationships in society, as well as about society itself. Luke's careful portrayal of commensality in LukeActs provides valuable biblical guidelines for how food and eating habits can be utilised in the formation of relationships in society; they have the potential for providing us with the key ingredients for a recipe for the formation (or generation) of social capital. The data obtained in the focus group in Phepheni communicate a fair amount regarding the bonding, bridging and linking capital that is present in that church and village.

The above reflection on food and mankind's eating habits, specifically as related to the formation and detection of the presence of social capital, is closely related to what Versfeld calls pea soup. 'No pea is an island ...', (Versfeld 1983:13) ${ }^{15}$ he writes, whilst thinking about the relationship between God, human beings and, of course, soup. Pea soup and social capital thus are possibly more closely linked (or should this perhaps be bonded or bridged) to one another than one might suspect at first glance. So yes, what is presented here can perhaps be seen as a measurement and recipe for the pea soup we call social capital. Some of the Dutch co-workers in the research project might want to refer to this recipe for pea soup as a recipe for 'snert', ${ }^{16}$ but the entire research team is very welcome to join the author in his ritual-liturgical kitchen and help him to refine the measurements to improve the recipe.

\footnotetext{
15. He is alluding to John Donne's lines: 'No man is an island, entire of itself $(\ldots)$ any man's death diminishes me, because I am involved in mankind (...)'.

16. Snert (Afrikaans): rubbish, nonsense, rot, trash; snert (Dutch): pea soup; something really bad.
} 


\section{REFERENCES}

Barnard, M., 2000, Liturgiek als wetenschap van christelijke riten en symbolen [Liturgics as the science of Christian rites and symbols], Vossiuspers, Amsterdam.

Braun, W., 1995, Feasting and social rhetoric in Luke 14, Society for New Testament Studies. Monograph Series 85, Cambridge University Press, New York.

Cilliers, J.H. \& Wepener, C.J., 2007, 'Research on liturgy and the generation of social capital in contexts of poverty. A South African exploration', International Journal of Practical Theology 11(1), 39-55.

Cussons, S., 1997, ' $n$ Engel deur my kop. ' $n$ Keuse uit haar religieuse gedigte [Religious poems by Sheila Cussons], Tafelberg, Cape Town.

De Visscher, J., 1996, Een te voltooien leven [A completed life], Kok Agora, Kampen.

Douglas, M., 1966, Purity and Danger. An analysis of concepts of pollution and taboo, Routledge, London/New York.

Douglas, M., 1971, 'Deciphering a meal', in C. Geertz (ed.), Myth, symbol and culture, pp. 61-81, W.W. Norton \& Company, New York.

Finger, R.H., 2007, Of widows and meals. Communal meals in the book of Acts, W.B. Eerdmans, Grand Rapids.

Fukuyama, F., Social capital: the problem of measurement, viewed 14 January 2009, from http://www.socialcapitalgateway. org/NV-eng-measurement.htm

Greschat, H.-J., 2008, 'Taboo', in E. Fahlbusch et al. (eds.), The Encyclopedia of Christianity Si-Z(vol.5, p.300),W.B.Eerdmans/ Brill, Grand Rapids, MI/Cambridge, UK.

NG Kerk, 1979, Handelinge van die Algemene Sinode van die NGK, NG Kerk, Pretoria.

Heil, J.P., 1999, The meal scenes in Luke-Acts. An audienceoriented approach, The Society of Biblical Literature Monograph Series Number 52, Society of Biblical Literature, Atlanta.

Loff, C., 1983, 'The history of a heresy', in J. de Gruchy \& C. Villa-Vicencio (eds.), Apartheid is a heresy, David Philip, Cape Town.

Love, S.L., 1995, 'Women and men at Hellenistic symposia meals in Luke', in F. Esler (ed.), Modelling early Christianity. Socialscientific studies of the New Testament in its context, Routledge, London/New York.

Nabudere, D.W., 2004, 'Ubuntu', in C. Villa-Vicencio \& E. Doxtader (eds.), Pieces of the puzzle. Keywords on reconciliation and transitional justice, pp. 10-16, IJR, Cape Town.

Neyrey, J.H., 1996, Reader's guide to meals, food and table fellowship in the New Testament, University of Notre Dame, Notre Dame.

Neyrey, J.H., 1991, 'Ceremonies in Luke-Acts: the case of meals and table-fellowship', in J.H. Neyrey (ed.), The social world of Luke-Acts. Models for interpretation, pp. 361-387, Hendrickson Publishers, Peabody.

Post, P.G.J., 2001a, 'Liturgical movements and feast culture. A Dutch research programme', in P.G.J. Post, G. Rouwhorst, L. van Tongeren \& A. Scheer (eds.), Christian feast and festival. The dynamics of Western liturgy and culture, Liturgia Condenda 12, pp. 3-43, Peeters, Leuven 2001.
Post, P.G.J., 2001b, 'Introduction and application. Feast as a key concept in a liturgical studies research design', in P.G.J. Post, G. Rouwhorst, L. van Tongeren \& A. Scheer (eds.), Christian feast and festival. The dynamics of Western liturgy and culture, Liturgia Condenda 12, pp. 47-77, Peeters, Leuven 2001.

Statistics South Africa, 2004, Population Census 2001, Religion Report, Statistics South Africa, Pretoria.

Stringer, M.D., 1989, 'Liturgy and anthropology: the history of a relationship', Worship 63(6), 503-521.

Swart, I., 2006, 'Churches as a stock of social capital for promoting social development in Western Cape communities', Journal of Religion in Africa 36(3\&4), 346-378.

Turner, V.W., 1965, 'Betwixt and between: the liminal period in rites de passage', in W.A. Lessa \& E.Z. Vogt (eds.), Reader in comparative religion. An anthropological approach, pp. 234-243, Harper \& Row, New York.

Turner, V.W., 1969, The ritual process. Structure and anti-structure, Routledge \& Kegan Paul, London.

Turner, V.W., 1972, 'Passages, margins and poverty: religious symbols of communitas', Worship 46(7), 390-412.

Van Gennep, A., 1996, 'Territorial passages and the classification of rites', in R.L. Grimes (ed.), Readings in ritual studies, pp. 529-536, Prentice Hall, Upper Saddle River.

Van Wiele, J., 2007, 'Mary Douglas' Purity and Danger revisited', Jaarboek voor liturgie-onderzoek 23, 177-209.

Versfeld, M., 1983, The philosopher's cookbook, Old Castle Books, Harpenden.

Wepener, C.J., 2002, 'Still because of the weakness of some? - A descriptive exploration of the Lord's Supper in South Africa, 1948-2002', Jaarboek voor liturgie-onderzoek 18, 139-158.

Wepener, C.J., 2005, 'Researching rituals. On the use of participatory action research in liturgical studies', Praktiese Teologie in Suid-Afrika 20(1), 109-127.

Wepener, C.J., 2006a, 'Participation and power: Opportunities for method and theory in liturgical research from a changing (Dutch Reformed) South African liturgical landscape', Jaarboek voor liturgie-onderzoek 22, 49-66.

Wepener, C.J., 2006b, 'The object and aim of multi-disciplinary liturgical research', Scriptura 93, 384-400.

Wepener, C.J., 2009, From fast to feast. A ritual-liturgical exploration of reconciliation in South African cultural contexts, Liturgia Condenda 19, Peeters, Leuven.

Wepener, C.J., 2010, Aan tafel met Jesus [With Jesus at the table], Wellington, Bybelmedia.

Wepener, C.J., Swart, I., Ter Haar, G. \& Barnard, M., 2010, 'The Role of Religious Ritual in Social Capital Formation for Poverty Alleviation and Social Development. Theoretical and Methodological Points of Departure of a South African Exploration', Religion E Theology 17 (1\&2) 61-82.

World Bank, n.d., Measuring social capital, viewed 14 January 2009, from www.worldbank.org/ 